\title{
The study of adverse changes in diesel fuel during its storage
}

\section{Badanie niekorzystnych zmian w oleju napędowym zachodzących w czasie jego magazynowania}

\author{
Magdalena Żółty, Jan Lubowicz \\ Oil and Gas Institute - National Research Institute
}

\begin{abstract}
Research on the impact of the storage process on the quality parameters of diesel oil containing $7 \%(V / V)$ FAME was carried out and six test stands for fuel storage were designed and constructed as part of the work. Their construction was based on materials resistant to diesel oil containing fatty acid methyl esters. The tests involved the selection of additives (two defoaming agents and one depressant, which can be added to the fuel at each stage of its production in the form of a package or as independent additives), which are suspected of drop out of the diesel fuel formulation during storage, which favors instability of its physicochemical and utility properties. Based on the diesel fuel purchased at the petrol station, the abovementioned additives were used to compose six samples. The authors assumed that the storage conditions represented the average annual temperature and humidity in Poland. In order to ensure the above conditions, the test stands together with the tested fuel samples were placed for a period of six weeks in a climatic chamber. The scope of physicochemical and applied tests was wide and selected in such a way as to monitor the properties of diesel oil for their constancy during storage. The test properties included mainly those that allowed to confirm the hypothesis regarding problems with the stability of defoamers and depressants in fuel. The initial samples and the samples collected after three and six weeks of storage in the climatic chamber from the upper layer and the bottom layer of the test stands were subjected to testing. The tests outcome quite ambiguous. The results of the determination of the foaming tendency of the tested diesel oil samples did not allow for unambiguous confirmation or refutation of the hypothesis of the work. In the case of a depressant, based on the results of low temperature properties, mainly the temperature of blocking the cold filter, a slight tendency to accumulate it in the lower layers of fuel in test stands could be observed. Oxidation stability of the tested fuel samples was maintained throughout the storage period at an almost constant, high level. There were no significant differences between the results determined for the samples taken from the upper and lower layers, which allows to conclude that antioxidant additives remain in the fuel regardless of the time of storage. The results of the determination of tendency to blocking the filter indicate a small amount of impurities and components in the tested diesel fuels that would impair its filterability. On the other hand, the results of the determination of the tendency to blocking the filter after cooling down CSFBT $(-1)$ may indicate problems with the depressant fast enough integration into fuel formula. In spite of the relatively high humidity, varying in a fairly wide range, the water content in the tested diesel fuel samples did not change to a large extent during storage.
\end{abstract}

Key words: diesel fuel, storage, defoamers, depressants.

STRESZCZENIE: W ramach pracy przeprowadzono badania wpływu procesu magazynowania na parametry jakościowe oleju napędowego zawierającego 7\% (V/V) FAME, zaprojektowano i skonstruowano sześć stanowisk badawczych do przechowywania paliwa. Do ich budowy wykorzystano materiały odporne na działanie olejów napędowych zawierających estry metylowe kwasów tłuszczowych. Do badań wytypowano dodatki (dwa przeciwpienne i jeden depresator, które mogą być dodawane do paliwa na każdym etapie jego produkcji $\mathrm{w}$ postaci pakietu lub jako niezależne dodatki) podejrzane o wypadanie $\mathrm{z}$ formulacji oleju napędowego $\mathrm{w}$ czasie magazynowania i przyczynianie się w ten sposób do niestabilności jego właściwości fizykochemicznych i użytkowych. $Z$ udziałem wyżej wymienionych dodatków zestawiono sześć próbek na bazie oleju napędowego zakupionego na stacji paliw. Autorzy przyjęli, że warunki magazynowania bẹdą odpowiadały średniej rocznej temperaturze i wilgotności powietrza w Polsce. W celu zapewnienia powyższych warunków stanowiska badawcze wraz z badanymi próbkami paliwa umieszczono na okres sześciu tygodni w komorze klimatycznej. Zakres prowadzonych badań fizykochemicznych i użytkowych był szeroki i dobrany w taki sposób, aby monitorować właściwości oleju napędowego pod kątem ich niezmienności w czasie magazynowania. Głównie chodzi o właściwości, które pozwalały na potwierdzenie hipotezy dotyczącej problemów ze stabilnością dodatków przeciwpiennych i depresatorów w paliwie. Przebadano próbki wyjściowe oraz próbki pobrane po 3 i 6 tygodniach przechowywania w komorze klimatycznej z warstwy górnej i warstwy dennej stanowisk badawczych. Uzyskano dość niejednoznaczne wyniki badań. Wyniki oznaczenia skłonności do pienienia badanych próbek olejów napędowych nie pozwoliły na jednoznaczne potwierdzenie lub obalenie stawianej w pracy hipotezy. W przypadku depresatora na podstawie wyników właściwości

Corresponding author: M. Żółty, e-mail: magdalena.zolty@inig.pl

Article contributed to the Editor 13.12.1018. Approved for publication 13.09.2019 
niskotemperaturowych, głównie temperatury zablokowania zimnego filtru, można zauważyć niewielką tendencję do kumulowania się go w niższych warstwach paliwa w stanowiskach badawczych. Stabilność oksydacyjna badanych próbek paliw utrzymywała się przez cały okres magazynowania na niemal niezmiennym, wysokim poziomie. Nie zaobserwowano zdecydowanych różnic pomiędzy wynikami oznaczonymi dla próbek pobranych z warstwy górnej i z dolnej, co pozwala na stwierdzenie, że dodatki przeciwutleniające utrzymują się w paliwie niezależnie od czasu magazynowania. Wyniki oznaczenia tendencji do blokowania filtra świadczą o niewielkiej ilości zanieczyszczeń i składników w badanych olejach napędowych, które pogarszałyby ich filtrowalność. Z kolei wyniki oznaczenia tendencji do blokowania filtra po wychłodzeniu CSFBT(-1) mogą świadczyć o problemach z odpowiednio szybkim wkomponowywaniem się depresatora do formuły paliwa. Pomimo stosunkowo dużej wilgotności powietrza, wahającej się w dość szerokim zakresie, zawartość wody w badanych próbkach oleju napędowego nie zmieniała się w dużym stopniu w czasie magazynowania.

Słowa klucze: olej napędowy, magazynowanie, dodatki przeciwpienne, depresatory.

\section{Introduction}

Diesel fuel, usually obtained from petroleum distillates, is intended for use in diesel engines, where a mixture of air and fuel is rapidly produced in the combustion chamber. Sprayed at high pressure, injected fuel mixes with hot air, evaporates and ignites. The compressed air pressure is $3-4 \mathrm{MPa}$ and the temperature amounts to $550-650^{\circ} \mathrm{C}$. High-quality diesel fuel should ensure uninterrupted fuel supply in any regime, easy engine start-up, rapid formation of a combustible mixture, easy ignition, uniform combustion, low corrosion of engine parts and a minimal tendency to form soot and resin sediments. It must meet stringent quality requirements defined in PN-EN 590 + A1:2017-06 (PN-EN 590+A1:2017-06).

Diesel fuel is a complex mixture of hydrocarbons, which also contains small amounts of compounds of other types and refining additives. Long-term storage of such a mixture may trigger oxidation, condensation and evaporation processes and other reactions dependent on storage conditions. These processes can contribute to such a change in the property characteristics that it will go beyond the limits imposed by the standard.

Diesel engines are used in many transport vehicles and in machines that work both indoor and outdoor, in places where fuel can only be delivered seasonally, which poses a problem of maintaining fuel properties for quite a long period of time. The fuel must maintain the required quality parameters imposed by the standard during storage under different climatic conditions, in tanks made of different materials. Two more problems with long-term storage can be mentioned. First, it is not always possible to perform a complete fuel analysis in accordance with standard test methods. However, if it is known which of the quality parameters in the case of long-term storage may not meet the normative ranges, the scope of testing of this fuel may be limited only to these characteristics and then we obtain approximate assessment of quality.

Secondly, if the fuel partially lost its quality during longterm storage, it is necessary to find a way to restore the required level of properties by blending it with appropriate additives or a portion of high-quality fuel.
The increase in oil prices, depletion of its resources and numerous legal regulations regarding the need to protect the natural environment are the main factors that contributed to the search for and popularization of alternative fuels, the example of which can be fatty acid methyl esters, which are biodegradable, environmentally friendly raw materials used as a biocomponent for diesel fuels (FAME) (Werther, 2009; Mori, 2009; Chen et al., 2010; Devendra et al., 2014). Biodiesel is a mixture of fatty acid methyl esters obtained from vegetable oils and animal fats. Unlike hydrocarbon oil, it is biodegradable, non-toxic and free of sulfur and harmful aromatic hydrocarbons. In addition, it ensures lower emission of harmful substances into the atmosphere with exhaust gases compared to conventional diesel oil (Meng et al., 2008; Banerjee and Chakraborty, 2009; Patil and Deng, 2009; Leung et al., 2010). However, the long-term storage of fuels containing FAME may create problems. The presence of unsaturated bonds in the ester molecule makes them more susceptible to oxidation or autoxidation processes. The oxidation stability of the esters is not directly dependent on the amount of double bonds, but it correlates with the total amount and position of allyl and bis-allyl carbon adjacent to the double bond. The use of antioxidant additives slows down the oxidation process and, to a certain extent, improves fuel stability (Fang and McCornick, 2006; Tang et al., 2008; Sacha 2018). Conventional diesel fuels as well as biodiesel must be characterized by the invariability of their physicochemical and operational properties from the moment of their manufacture or composition, through transport and distribution, to the final user. It is not easy, because they are exposed to various factors that have an impact on the activation and acceleration of unfavorable processes leading to a deterioration of the quality of fuel (Urzędowska, 2008). The time in which the fuel will be used is variable and difficult to specify. On average, standard diesel used as motor fuel for mobile applications is consumed within 18 to 24 days from the date of its production, and the recommended storage time is no longer than 6-12 months, when the ambient temperature exceeds $30^{\circ} \mathrm{C}$ or 12 months, when the temperature does not exceed $20^{\circ} \mathrm{C}$ (BP, Long Term Storage of Diesel). 
Contemporary low-sulfur diesel is not the same fuel that was produced a few or a dozen years ago. It contains a number of non-kerosene components, which shortens the permissible storage time compared to classic kerosene-derived fuels and increases the requirements for storage conditions. Directive 2009/30/EC of the European Parliament and of the Council of 23 April 2009 amending Directive 98/70/EC relating to the specification of petrol and diesel fuels and introducing a mechanism to monitor and limit greenhouse gas emissions and amending Council Directive 1999/32/EC relating to the specification of fuels used by inland waterway vessels and repealing Directive 93/12/EEC - allowed Member States to market the diesel fuel containing more than $7 \%$ of fatty acid methyl esters (FAME) (Żółty, 2018).

Stability of fuel during storage is defined as its resistance to changes in physical and chemical properties caused by interaction with the environment (Yang et al., 2014). During storage, diesel fuel is subjected to chemical processes, commonly known as aging processes, which include the reaction of diesel fuel components with oxygen from the air, resulting in a deterioration of the quality of the fuel. This may also result in the formation of deposits that do not burn well in the combustion chamber, which in turn leads to the formation of deposits on its elements, i.e. soot and wax, and may eventually lead to the failure of the aggregate. Degraded fuel with sludge causes clogging of filters, increased consumption and may lead to operational problems of the aggregates.

Many factors affect the acceleration of aging processes of stored fuels for self-ignition engines. e.g.:

- contact with metals, i.e. zinc and copper and their alloys;

- the presence of water, which promotes the growth of fungi and bacteria, and the products of their metabolism lead to the destabilization of the quality of fuel;

- high temperature and solar exposure;

- condition of tanks and pipelines - dust, dirt and corrosion products contain substances that destabilize fuel, i.e. copper and zinc.

The conducted analysis of leading fuel manufacturers in Poland shows that they are struggling with the problem of maintaining desired properties of diesel fuel during transport and its longer storage. The potential source of these problems is thought to include the possibility of drop out of refining additives from the fuel formulation, mainly defoamers. On the other hand, research conducted within the CEN WG 24 working group also indicates a problem related to the stability of depressants in the composition of diesel fuel. On the basis of literature analysis in this respect, it can be concluded that the problem of stability of defoamers and depressants in diesel fuel has not been studied too broadly. With this in mind, the Institute attempted to develop this issue.

\section{Experimental part}

The implementation of this research work was intended to identify unfavorable changes that can potentially occur during the storage of diesel fuel under given ambient conditions. Information from the Polish market indicates the possibility of drop out of certain additives included in the refining package during fuel storage. For this purpose, the test stands were constructed of materials resistant to the use of diesel fuels containing FAME, which were placed in a climatic chamber allowing to simulate the given ambient conditions for a specific period of time. The research program included a compilation of several diesel fuel samples of different type and content of selected additives, as well as performing tests in the field of physicochemical properties selected in such a way that it would be possible to monitor the tendency to drop out of the fuel formulation.

In order to conduct planned tests to identify possible adverse changes occurring during fuel storage, diesel fuel containing $7 \%(V / V)$ FAME was purchased at the petrol station. The fuel was divided into six separate samples, to which defoamers and a depressant were introduced in various compositions. Tables 1 and 2 list the properties of purchased diesel fuel declared by the manufacturer and additional properties in $\mathrm{INiG}-\mathrm{PIB}$. On this basis, it was found that the fuel meets the requirements of the PN-EN 590 specification. In order to investigate adverse changes in diesel properties related to, among others, the socalled loss of refining additives during its storage, two defoamers (modified siloxane) and one depressant were selected for testing. The dosage level of the defoamer was set at $5 \mathrm{ppm}$ and the depressant at $300 \mathrm{ppm}$.

Six diesel fuel samples with a capacity of 65 liters each were prepared to determine the effect of diesel storage conditions on its properties in the laboratory. The sample marked as sample 1 is a reference sample, it is a fuel purchased at a petrol station. The list of diesel fuel samples:

Sample 1 - diesel fuel purchased at the fuel station; Sample 2 - diesel fuel from the petrol station, to which $5 \mathrm{ppm}$ of defoamer 1 was introduced;

Sample 3-diesel fuel from the petrol station, to which $5 \mathrm{ppm}$ of defoamer 2 was introduced;

Sample 4 - diesel fuel from the petrol station, to which $5 \mathrm{ppm}$ of defoamer 1 and 300 ppm of the depressant were introduced; Sample 5 - diesel fuel from the petrol station, to which $5 \mathrm{ppm}$ of defoamer 2 and 300 ppm of the depressant were introduced; Sample 6 - diesel fuel from the petrol station, to which $300 \mathrm{ppm}$ of the depressant was introduced.

The fuel samples were stored in constructed test stands in a climatic chamber, which allowed to maintain stable climatic conditions for a given period of time. The selection of conditions in which samples of the fuels were stored for 6 weeks was 
Table 1. Properties of diesel fuel declared by the manufacturer

Tablica 1. Właściwości oleju napędowego deklarowane przez producenta

\begin{tabular}{|c|c|c|c|}
\hline Parameter & Testing method & Unit & Test result \\
\hline Density at $15^{\circ} \mathrm{C}$ & PN-EN ISO 12185:2002 & $\mathrm{kg} / \mathrm{m}^{3}$ & 836.6 \\
\hline $\begin{array}{l}\text { Distillation characteristics at atmospheric pressure } \\
- \text { up to the temperature of } 250^{\circ} \mathrm{C} \text { it distils } \\
\text { - up to the temperature of } 350^{\circ} \mathrm{C} \text { it distils } \\
-95 \%(V / V) \text { distils to the temperature }\end{array}$ & PN-EN ISO 3405:2012 & $\begin{array}{c}\%(V / V) \% \\
(V / V){ }^{\circ} \mathrm{C}\end{array}$ & $\begin{array}{c}36.7 \\
94.7 \\
351.1\end{array}$ \\
\hline Kinematic viscosity at a temperature of $40^{\circ} \mathrm{C}$ & PN-EN ISO 3104:2004 & $\mathrm{mm}^{2} / \mathrm{s}$ & 2.721 \\
\hline Cetane index & PN-EN ISO 4264:2010 & - & 53.4 \\
\hline Cold filter plugging point & PN-EN 116:2015-09 & ${ }^{\circ} \mathrm{C}$ & -8 \\
\hline Flash point & PN-EN ISO 2719:2016-08 & ${ }^{\circ} \mathrm{C}$ & 66.0 \\
\hline Sulphur content & PN-EN ISO 20846:2012 & $\mathrm{mg} / \mathrm{kg}$ & 8.5 \\
\hline Water content & PN-EN ISO 12937:2005 & $\%(m / m)$ & 0.009 \\
\hline Carbon residue (from $10 \%$ distillation residue) & PN-EN ISO 10370:2014-12 & $\%(m / m)$ & 0.01 \\
\hline Total contamination & PN-EN 12662:2014-05 & $\mathrm{mg} / \mathrm{kg}$ & below 12.0 \\
\hline Copper corrosion $\left(3 \mathrm{~h}\right.$, at $\left.50^{\circ} \mathrm{C}\right)$ & PN-EN ISO 2160:2004 & class & class 1 \\
\hline Cloud point & PN-ISO 3015:1997 & ${ }^{\circ} \mathrm{C}$ & -8 \\
\hline Cetane number & PN-EN ISO 5165:2003 & - & 51.8 \\
\hline Ash residue & PN-EN ISO 6245:2008 & $\%(m / m)$ & below 0.001 \\
\hline Oxidation stability & PN-EN ISO 12205:2011+Ap1:2011 & $\mathrm{g} / \mathrm{m}^{3}$ & 6 \\
\hline Aromatic hydrocarbon types content & PN-EN 12916:2016-03 & $\%(m / m)$ & 2.4 \\
\hline Manganese content & PN-EN 16576:2014-12/Ap1:2017-11 & $\mathrm{mg} / \mathrm{l}$ & below 0.5 \\
\hline Lubricity, corrected wear scar diameter (wsd 1.4 ) at $60^{\circ} \mathrm{C}$ & PN-EN ISO 12156-1:2016 & $\mu \mathrm{m}$ & 420 \\
\hline
\end{tabular}

based on the average annual temperature and humidity in our country. Fuel in depots is stored in large aboveground tanks (with a capacity of $\left.1000-20,000 \mathrm{~m}^{3}\right)$, and in the case of petrol stations, in underground tanks (with a capacity of $30-100 \mathrm{~m}^{3}$ ), where there are no large temperature fluctuations. Due to technical conditions it was possible to plan a fuel test only at one temperature, which is why, on the basis of meteorological data analysis, it was assumed that the storage will be carried out at a temperature of $10^{\circ} \mathrm{C}$ and with the humidity of about $60-80 \%$. These conditions were controlled throughout the duration of the test.

For the purposes of this research work, six identical test stands were designed and constructed for storing diesel fuel samples. The dimensions of the stands (the height of the liquid column
Table 2. Properties of diesel fuel additionally marked in INiG - PIB

Tablica 2. Właściwości oleju napędowego oznaczone uzupełniająco w INiG - PIB

\begin{tabular}{|l|l|c|c|}
\hline \multicolumn{1}{|c|}{ Parameter } & \multicolumn{1}{c|}{ Testing method } & Unit & Test result \\
\hline \hline Fatty acid methyl ester content & PN-EN 14078:2014 & $\%(\mathrm{~V} / \mathrm{V})$ & 6.6 \\
\hline Silicon content & ASTM D 7111-06 & $\mathrm{mg} / \mathrm{kg}$ & below 0.17 \\
\hline Cloud point & PN-ISO 3015:1997 & ${ }^{\circ} \mathrm{C}$ & -8 \\
\hline $\begin{array}{l}\text { Oxidation stability } \\
\text { Conductometric method }\end{array}$ & PN-EN 15751:2014 & $\mathrm{h}$ & 80.1 \\
\hline Filter blocking tendency (FBT) & ASTM D2068 & - & 1.03 \\
\hline $\begin{array}{l}\text { Cold soak filter blocking tendency (CSFBT(-1)) } \\
- \text { final pressure: } 21 \mathrm{kPa} \\
- \text { filtered sample amount: 300 ml }\end{array}$ & IP PM-ES/16 & - & 1.02 \\
\hline Total contamination & PN-EN 12662:2014 & $\mathrm{mg} / \mathrm{kg}$ & 5.8 \\
\hline $\begin{array}{l}\text { Foaming tendency } \\
- \text { foam volume } \\
- \text { time of foam disappearance }\end{array}$ & NF M 07-075:1997 & $\mathrm{ml}$ & 110 \\
\hline Water content & PN-EN ISO 12937:2005 & $\mathrm{mg} / \mathrm{kg}$ & 35 \\
\hline Cold filter plugging point & PN-EN 116:2015 & ${ }^{\circ} \mathrm{C}$ & -9 \\
\hline
\end{tabular}

and the diameter of the fuel tanks) were selected in such a way that observation of the process of sedimentation of pollutants and precipitation of refining additives could be carried out, while minimizing the amount of fuel, size and stand construction costs. These stands were made of materials resistant to diesel 
fuel containing fatty acid methyl esters, i.e. polypropylene and polyethylene. HD $100 \mathrm{DN}$ PE (polyethylene) pipe with a length of 200 centimeters, an internal diameter of $20 \mathrm{~cm}$ and a wall thickness of $7.7 \mathrm{~mm}$ was the body of the stand. Each pipe was threaded from the inside at a height of about $10 \mathrm{~cm}$, so that it was possible to attach the bottom of the tank. The bottoms were rolled and threaded from a polypropylene casting shaft with a diameter of $200 \mathrm{~mm}$ and a length of $1000 \mathrm{~mm}$. As the inner surface of each bottom has the shape of a small cone, it is possible for the sediment, which may contain a higher concentration of additives, to condense in this place. In addition, a hole was drilled in it, to which a valve was attached to allow the sampling of the lower layer. A fuel line, also resistant to diesel fuel, has been used as the sampling line (Fig. 1). During the testing of test stands, there was a problem of their leakage associated with the deformation of polyethylene pipes, which, despite the appropriate length of threads, did not maintain symmetry. In order to ensure tightness, metal clamps have been installed in all stands (Fig. 2). All stands were protected against possible overturning.

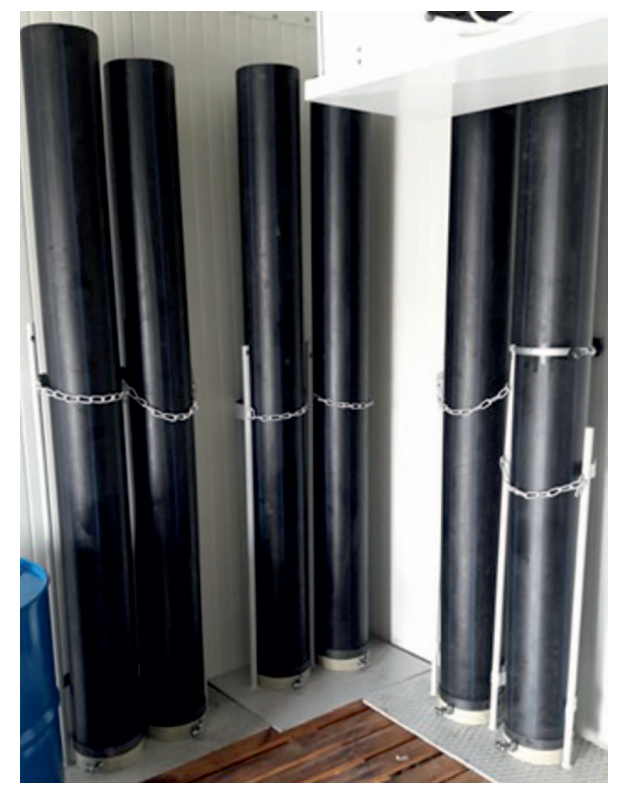

Fig. 1. Test stands for diesel fuel storage (photo: $\mathrm{INiG}-\mathrm{PIB}$ )

Rys. 1. Stanowiska badawcze do przechowywania olejów napędowych (fot. INiG - PIB)

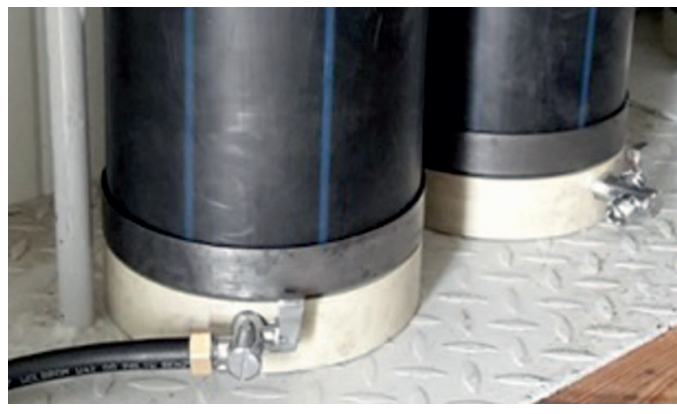

Fig. 2. Metal sealing clamps for test stands (photo: $\mathrm{INiG}-\mathrm{PIB}$ )

Rys. 2. Metalowe obejmy uszczelniające stanowisk badawczych (fot. INiG - PIB)
During the construction of test stands (e.g. during threading), no lubricants were used to facilitate the twisting of the structure or its sealing. In addition, the stands before being assembled and filled with test samples of diesel fuel were thoroughly cleaned, rinsed with clean water and dried.

The scope of testing diesel fuel samples has been selected to confirm the information from the market about the possibility of "drop out", of some refining additives from the diesel fuel formulation, mainly defoamers and the depressant. The scope of research was additionally enriched with oxidative stability studies. The table below presents the selected parameters together with test methods (Table 3).

Tests of these physicochemical properties were made for diesel fuel samples immediately after their preparation and filling of test stands (mean samples) and after 3 and 6 weeks of storage under given temperature conditions from the lower and the upper test stand layer. The sampling of the middle layer was omitted in order to eliminate the possibility of disturbing the volume of stored samples, which could affect the obtained test results. All results provided in the paper are the mean of at least two measurements.

Table 3. Summary of physicochemical tests carried out on diesel fuel samples

Tablica 3. Zestawienie badań fizykochemicznych jakim podlegały próbki olejów napędowych

\begin{tabular}{|l|l|}
\hline \multicolumn{1}{|c|}{ Marked property } & \multicolumn{1}{c|}{ Test method } \\
\hline \hline Silicon content & ASTM D 7111-16a \\
\hline Cloud point & PN-ISO 3015:1997 \\
\hline Oxidation stability & PN-EN 15751:2014 \\
\hline Filter blocking tendency & ASTM D 2068-11 \\
\hline Cold soak filter blocking tendency & IP PM-ES/16 \\
\hline Total contamination & PN-EN 12662:2014 \\
\hline Foaming tendency & NF M 07-075:1997 \\
\hline Water content & PN-EN ISO 12937:2005 \\
\hline Cold filter plugging point & PN-EN 116:2015 \\
\hline
\end{tabular}

\section{Results}

Figures 1 to 9 present the obtained results of laboratory tests for samples collected immediately after their compilation and for samples taken from the lower and upper layers after 3 and 6 weeks of storage under given conditions.

The tendency of diesel fuels to foam is one of the parameters that allow to monitor the effectiveness and stability of defoamers. The determination of the tendency to foaming of diesel fuel consists of measurements of two parameters: foam volume and its disappearance time (Figs. 3, 4). 
The determined foam volume for the tested initial diesel samples was varied. Sample 1 (diesel fuel from the petrol station) and sample 6 (diesel fuel from the petrol station containing an additional portion of the depressant) showed a similar tendency to create foam. In the case of samples 2 and 3 , to which the same amount of the two defoamers was introduced, a smaller volume of foam was observed in relation to samples 1 and 6. Comparing samples 1 and 3, these differences were insignificant, and the results were in the uncertainty of the method (i.e., $25 \mathrm{ml}$ ). For sample 2, the effectiveness of defoamer 1 was better than additive 2, which was introduced into sample 3 . The decrease in foam volume determined for sample 2 in relation to the foam volume for diesel fuel from the petrol station is around $40 \%$. On the other hand, for samples 4 and 5, to which, apart from defoamer, also a depressant was introduced, differences in the foam volume were not significant (within the uncertainty of the method) in relation to the diesel fuel from the station. The decrease in foam tendency was slightly more pronounced for sample 5 (a decrease of approximately $25 \%$ relative to sample 1).

In the samples collected from all test stands from the upper and lower level, the determined foam volume for individual tanks throughout the storage period was at a similar level. The distribution of results in nearly all cases was within the uncertainty of the method. However, it should be noted that no clear trends can be observed for the distribution of the result for samples taken from the top layer and from the bottom. In the area of the foam volume analyzed, no confirmation of the hypothesis concerning the tendency for the loss of defoamers from the fuel formulation was confirmed. Of course, this statement applies only to the range of analyzed active elements introduced into diesel fuel with selected additives. Based on the results obtained after the given storage times, it is also not possible to determine which of the defoamers used was more effective. In the case of introducing only additive 1 , the tendency to foam was lower than for additive 2 . The introduction of an additional portion of the depressant increased the propensity to fuel foaming.

The analysis of foam stability results, expressed as the time required for its disappearance, clearly indicates that for all the analyzed samples it is

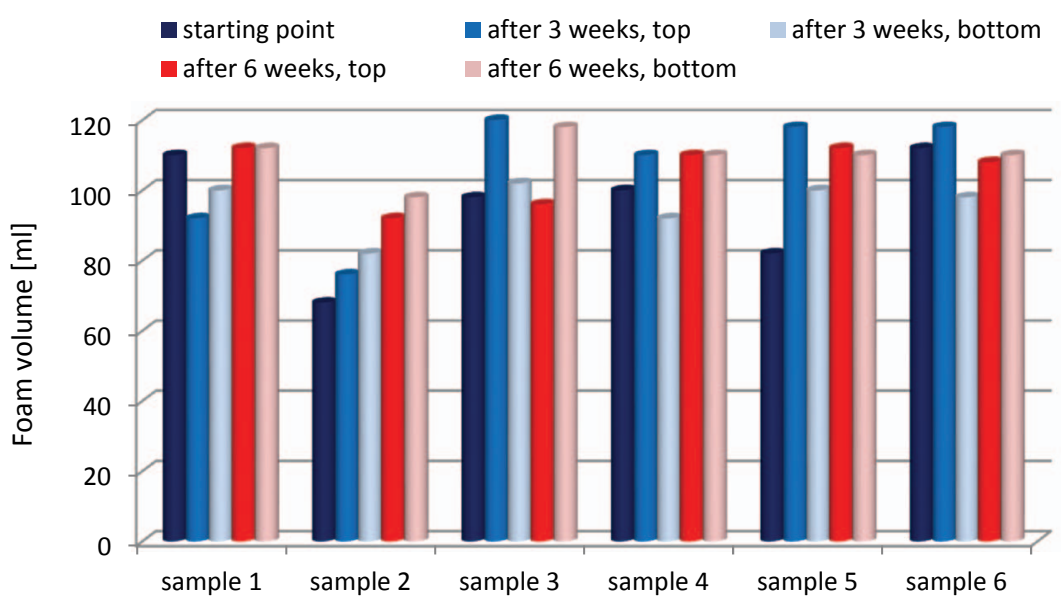

Fig. 3. Effect of storage time on foam volume in the composed diesel fuel samples

Rys. 3. Wpływ czasu magazynowania na objętość piany w skomponowanych próbkach oleju napędowego

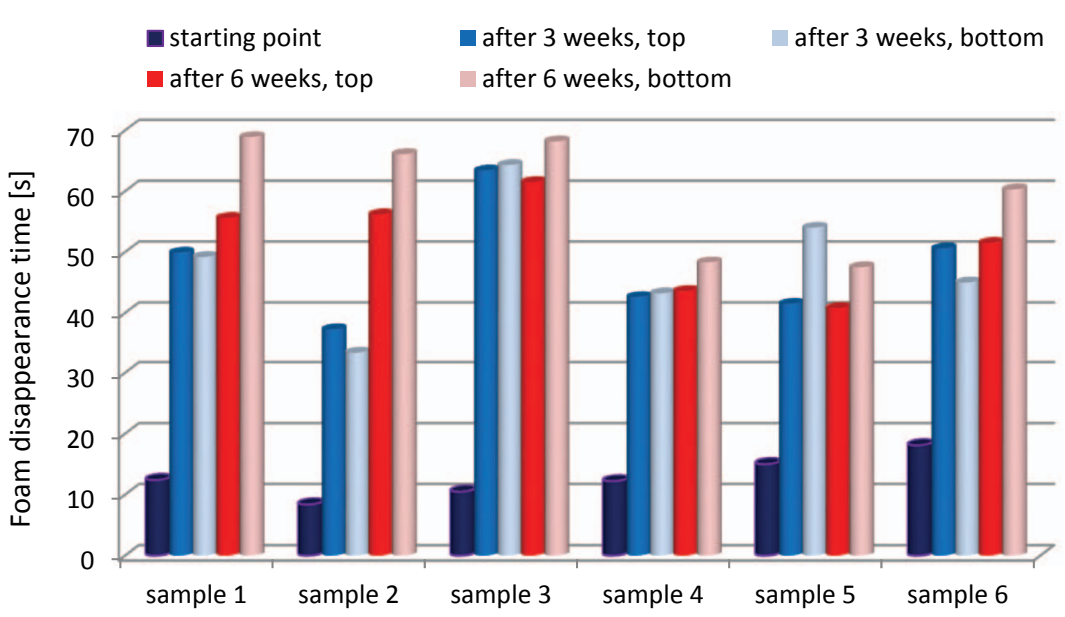

Fig. 4. Effect of storage time on foam disappearance in the composed diesel fuel samples

Rys. 4. Wpływ czasu magazynowania na czas zaniku piany w skomponowanych próbkach oleju napędowego

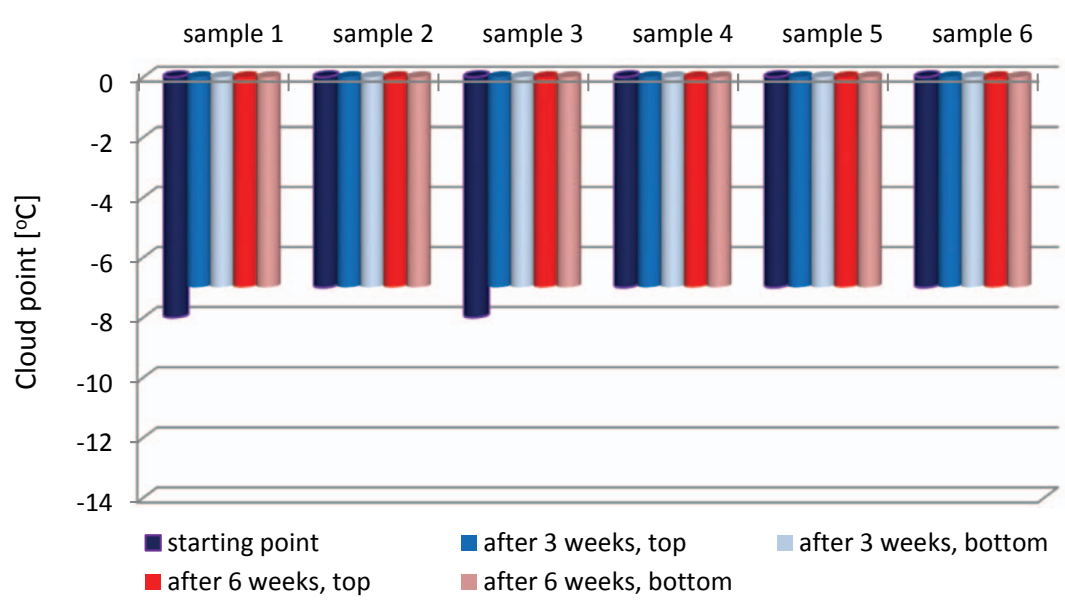

Fig. 5. Effect of storage time on the cloud point in the composed diesel fuel samples

Rys. 5. Wpływ czasu magazynowania na temperaturę mętnienia w skomponowanych próbkach oleju napędowego 
much shorter than for samples collected after 3 and 6 weeks of storage from both layers (for which time is at similar levels). Due to such a large difference in the obtained times of foam decay, it was decided to repeat the foam stability tests. The obtained test results were repeated. The authors do not quite know what can affect such a result. One of the hypotheses may be related to the loss of defoamers. In the first stage of the analysis, the difference in the results was supposed to be explained by the insufficient integration of defoamers with diesel fuel right after they were introduced. Perhaps an increase in the foam stability is related to the incompatibility of the additives with the original package of refining additives. However, this does not explain the increase in foam stability also in the diesel fuel sample from the petrol station, which was not refined, but could contain a defoamer that could have dropped out.

The value of cloud point in all samples for the entire duration of the test was determined at a constant level. All test results are within the uncertainty of the method. In this case, no difference was observed between the samples to which the depressant was introduced and the remaining samples. The result is the same for samples taken from the top and bottom layers. The analysis of the cloud point results does not indicate a tendency for sedimentation of n-paraffin hydrocarbons in the analyzed diesel fuel samples (Fig. 5).

Based on the above results, the cold filter plugging point (CFPP) decrease was observed for samples containing an additional portion of the depressant (samples 4, 5, and 6). In these samples, a small difference was observed between the samples collected from the top and from the bottom of the tank. Samples taken from the bottom have a slightly lower cold filter plugging point than those taken from the top. This may indicate a slight tendency for the depressant to accumulate in the lower layers of fuel in the tank. For samples 1, 2 and 3 (no depressant), CFPP remains unchanged throughout the storage period (all results are within the uncertainty of the method), (Fig. 6).

Oxidation stability determined for the analyzed samples of diesel fuels was almost unchanged at high levels throughout the storage period under given conditions. Possible deviations may result from high values of resistance to oxidation, while

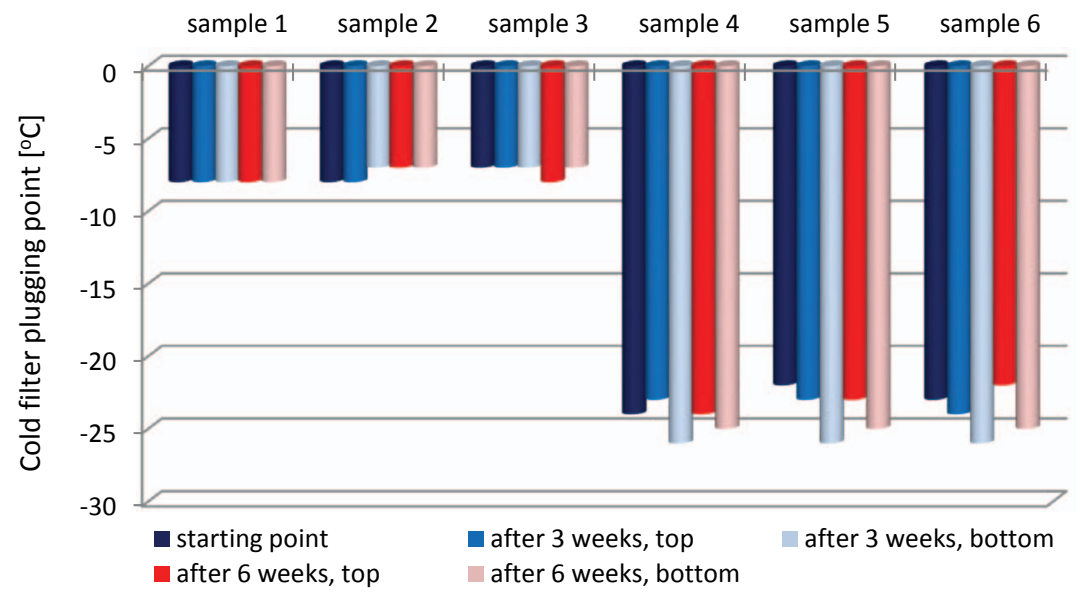

Fig. 6. Effect of storage time on the cold filter plugging point in the composed diesel fuel samples

Rys. 6. Wpływ czasu magazynowania na temperaturę zablokowania zimnego filtru w skomponowanych próbkach oleju napędowego

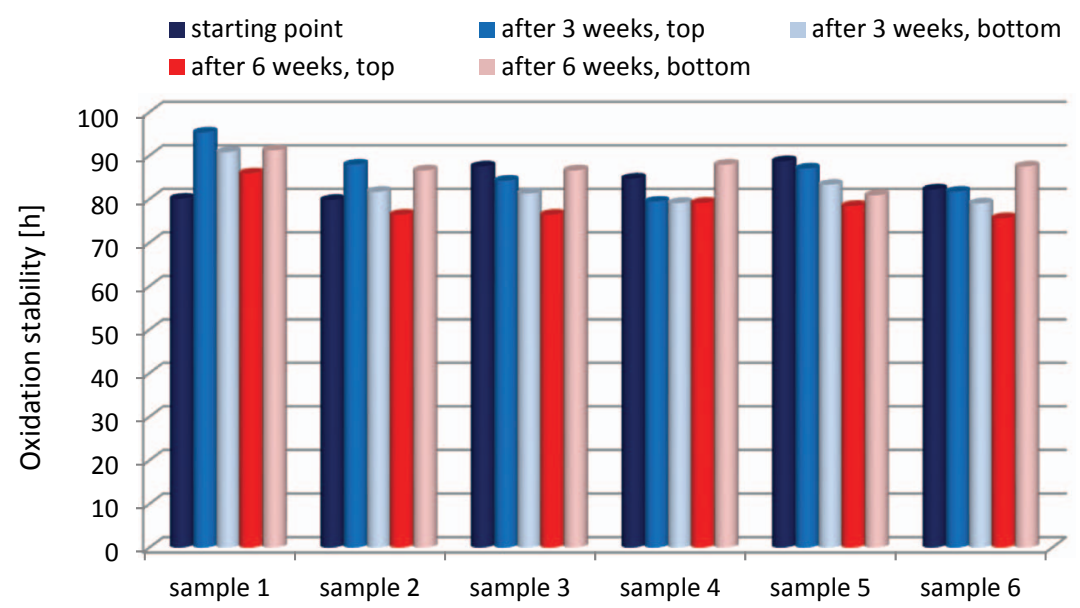

Fig. 7. Effect of storage time on the oxidation stability marked using the PN-EN 15751 method in the composed diesel fuel samples

Rys. 7. Wpływ czasu magazynowania na stabilność oksydacyjną oznaczoną metodą PN-EN $15751 \mathrm{w}$ skomponowanych próbkach oleju napędowego

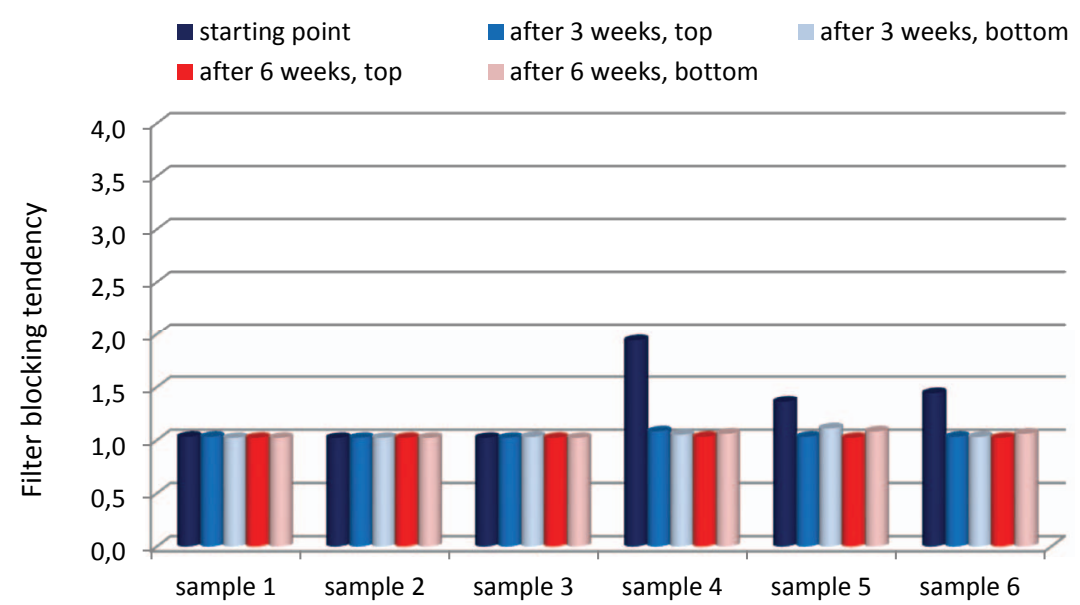

Fig. 8. Effect of storage time on the filter blocking tendency in the composed diesel fuel samples

Rys. 8. Wpływ czasu magazynowania na tendencję do blokowania filtru w skomponowanych próbkach oleju napędowego 
the precision of the method has been determined in the range up to $46 \mathrm{~h}$. The obtained test results indicate a stable distribution of antioxidant additives in the fuel. The obtained test results were similar irrespective of the layer from which the samples were collected (Fig. 7).

Obtained results of tests of filter blocking tendency in accordance with ASTM D 2068 for all samples are at a similar, low level (about 1.2) regardless of the storage time and the layer they were collected from. Only the initial sample of 4, 5 and 6 , for which the FBT value was determined at $1.94,1.36$ and 1.44 respectively stands out in this range. However, these levels are not high (the acceptable level for this parameter in diesel in the United Kingdom is 2.52). Likely precipitation of impurities negatively affecting filterability (Fig. 8).

In the case of determining the tendency to plug the cold soak filter blocking tendency the sample for a period of $16 \mathrm{~h}$ at $-1^{\circ} \mathrm{C}(\mathrm{CSFBT}(-1))$, the obtained results are more different than those obtained by the non-cooling method (FBT). In the case of a diesel fuel sample from the fuel station and samples where $5 \mathrm{ppm}$ defoamers were introduced, the CSFBT $(-1)$ results are almost equally low. Significantly higher results were obtained for samples additionally refined not only with defoamer, but also with the depressant and in the sample to which only the depressant was additionally introduced. The highest CSFBT values $(-1)$ were obtained for the initial samples and lower values in the samples after 3 and 6 weeks of storage. Such results may indicate an insufficient integration of the depressant into the diesel formula immediately after its introduction. Over time, this property is slightly improved. However, this hypothesis is not confirmed by the results of CFPP, which indicate the effective operation of the depressant throughout the storage period (6 weeks), (Fig. 9).

Obtained results of testing the content of total contamination for all samples indicate the precipitation during the storage period. Higher content of contaminations was observed in samples taken from the bottom layer. However, their amount determined in the initial samples after 3 or 6 weeks was varied. It can also not be ruled out that a certain amount of deposits could also cling to the side walls of the tank (pipe) in which the fuel was stored. The largest amount of contaminations in

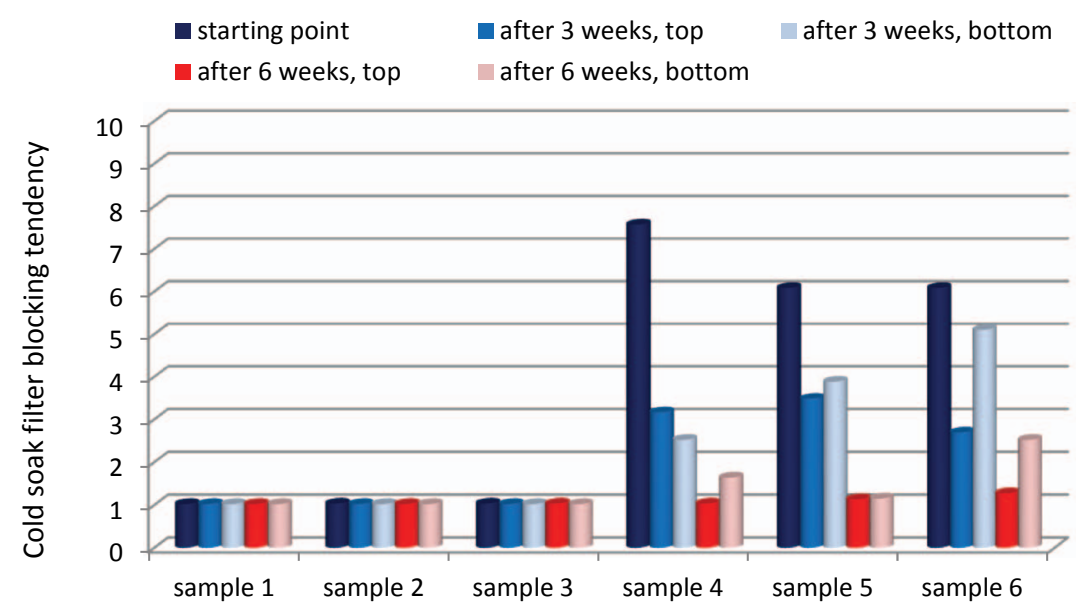

Fig. 9. Effect of storage time on the cold soak filter blocking tendency in the composed diesel fuel samples

Rys. 9. Wpływ czasu magazynowania na tendencję do blokowania filtru po wychłodzeniu w skomponowanych próbkach oleju napędowego

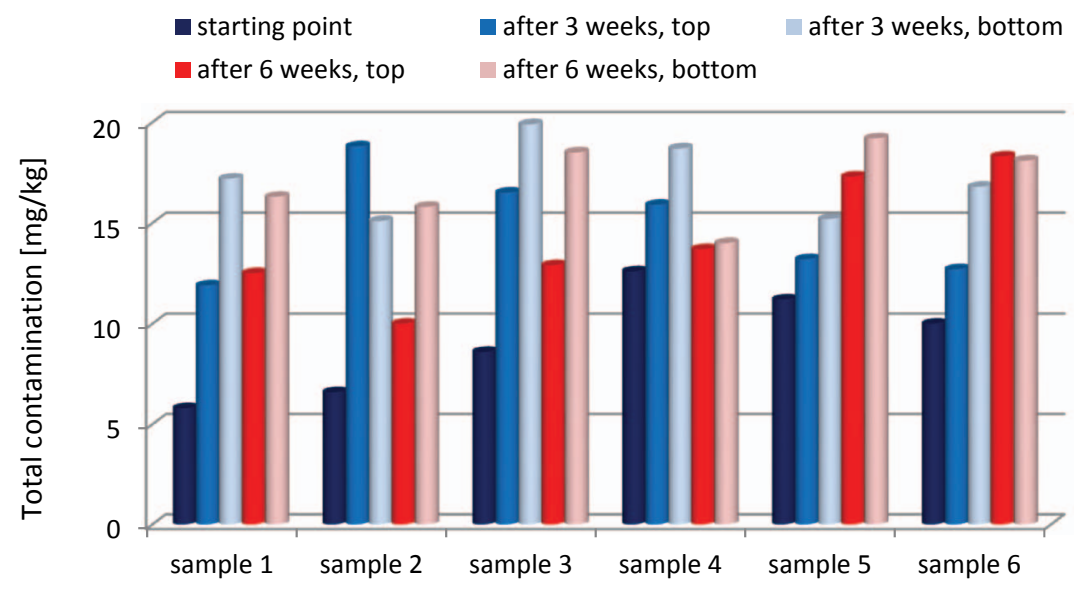

Fig. 10. Effect of storage time on the total contamination in the composed diesel fuel samples

Rys. 10. Wpływ czasu magazynowania na zawartość zanieczyszczeń w skomponowanych próbkach oleju napędowego

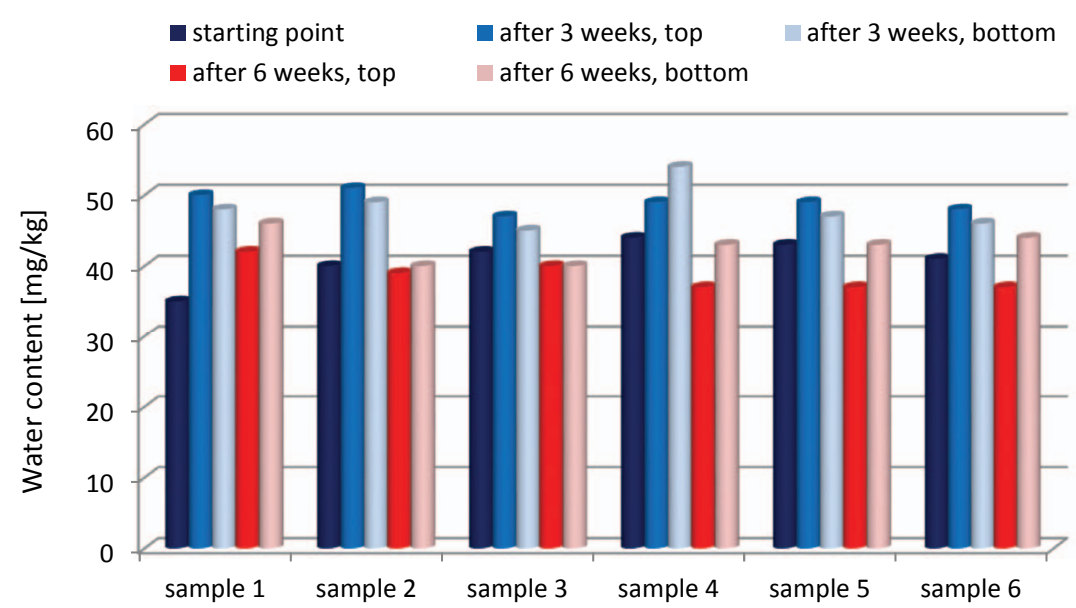

Fig. 11. Effect of storage time on the water content in the composed diesel fuel samples

Rys. 11. Wpływ czasu magazynowania na zawartość wody w skomponowanych próbkach oleju napędowego 
the initial samples was determined in diesel fumes enriched with a mixture of defoamers with a depressant. However, this did not translate into the content of sediments after the storage period (Fig. 10).

In all tested samples, both initial and those collected after 3 and 6 weeks of storage from the upper and lower layers, the determined water content was at a similar, low level (results were within the uncertainty of the method, which for the obtained research results was around $30 \mathrm{mg} / \mathrm{kg}$ ). No significant difference was observed between the water content of the bottom samples and the samples taken from the top layer. Despite the storage of samples in open tanks at relatively high humidity, the water did not accumulate. Probably this may result from a small contact area $\left(0.03 \mathrm{~m}^{2}\right)$ between fuel and air (Fig. 11).

\section{Conclusions}

1. The tests have shown that the antioxidant additive found in the purchased B7 diesel fuel is maintained evenly throughout the entire fuel storage period.

2. The depressant introduced into fuels effectively reduces the temperature of CFPP (to below $-20^{\circ} \mathrm{C}$ ) and it also shows a slight tendency to accumulate in the bottom layer, which is indicated by lower CFPP results in samples collected from the tank bottom.

3. The filterability tests including the FBT, CSFBT methods indicate that the introduction of additional additives to diesel fuel did not affect the deterioration of its tendency to plug the filter, which may indicate the compatibility of the additives used with the package present in the diesel fuel before.

4. Tests conducted according to PN-EN 12662 showed that all samples were characterized by a tendency to precipitate deposits. Their quantity significantly increased during storage, but they did not show any tendency to sedimentation.

This paper was written on the basis of the statutory work entitled: Badanie niekorzystnych zmian $w$ ON zachodzacych $w$ czasie jego magazynowania - the work of the Oil and Gas Institute - National Research Institute was commissioned by the Ministry of Science and Higher Education; order numer: 0091/TE/2018, archive number: DK-4100-0083/2018.

\section{References}

Banerjee A., Chakraborty R., 2009. Parametric sensitivity in transesterification of waste cooking oil for biodiesel production - a revive. Resources, Conservation and Recycling, 53(9): 490-497. DOI : 10.1016/j.resconrec.2009.04.003.

BP, Long Term Storage of Diesel. https://www.bp.com/content/dam/ bp-country/en_au/media/fuel-news/long-term-storage-diesel. $\mathrm{pdf}+\& \mathrm{~cd}=4 \& \mathrm{hl}=\mathrm{pl} \& \mathrm{ct}=\mathrm{clnk} \& \mathrm{gl}=\mathrm{pl}($ dostęp: 22.11 .2018$)$.
Chen K.S., Lin Y.C., Hsieh L.T., Lin L.F., Wu C.C., 2010. Saving energy and reducing pollution by use of emulsified palm-biodiesel blends with bio-solution additives. Energy, 36: 2043-2048. DOI: 10.1016/j.energy.2010.01.021.

Devendra S.R., Girdhar J., Bhawna Y.L., Avanish K.T., Sudesh M., 2014. Impact of additives on storage stability of Karanja (Pongamia Pinnata) biodiesel blends with conventional diesel sold at retail outlets. Fuel, 120: 30-37.

Fang H., McCornick R., 2006. Spectroscopic study of biodiesel degradation pathway. SAE Technical Paper: 2006-01-3300.

Leung D., Wu X., Leung K., 2010. A review on biodiesel production using catalyzed transesterification. Applied Energy, 87(4): 1083-1095. DOI: 10.1016/j.apenergy.2009.10.006.

Meng X., Chen G., Wang Y., 2008. Biodiesel production from waste cooking oil via alkali catalyst its engine test. Fuel Processing Technology, 89(9): 851-857. DOI: 10.1016/j.fuproc.2008.02.006.

Mori S., 2009. Development of utilization technologies of biomass energy. Journal of Environ. Eng. and Manage. 19: 67-72.

Patil P., Deng S., 2009. Optimalization of biodiesel production from edible and non-edible vegetable oils. Fuel, 88(7): 1302-1306.

Sacha D., 2018. Wpływ jakości estrów metylowych kwasów tłuszczowych na niskotemperaturowe właściwości użytkowe paliw silnikowych. Nafta-Gaz, 2: 148-155. DOI: 10.18668/NG.2018.02.09.

Tang H., Wang A., Salley S., Simon-Ny K., 2008. The effect of natural and synthetic antioxidants on the oxidative stability of biodiesel. Journal Am. Oil Chemical Soc., 85: 373-382. DOI 10.1007/s11746-008-1208-z.

Urzędowska W., 2008. Opracowanie metody badania stabilności podczas przechowywania biopaliw do zasilania silników ZS. Praca naukowa Instytutu Technologii Nafty nr 0086/TE/2008.

Werther J., 2009. Sustainable and energy-efficient utilization of biomass by co-combustion in large-scale power station. Journal of Environ. Eng. and Manage. 19: 135-144.

Yang Z., Hollebone B.P., Wang Z., Brown C., Landriault M., 2014. Storage stability of commercially available biodiesel and their blends under different storage conditions. Fuel, 115: 366-377.

Żółty M., Krasodomski W., 2018. Stabilność oksydacyjna estrów metylowych kwasów thuszczowych stanowiących samoistne paliwo lub biokomponent olejów napędowych. Nafta-Gaz, 5: 399-405. DOI: $10.18668 /$ NG.2018.05.08

\section{Legal and normative acts}

PN-EN 590+A1:2017-06 Paliwa do pojazdów samochodowych Oleje napędowe - Wymagania i metody badań.

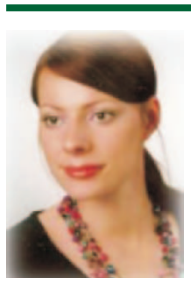

Magdalena ŻÓŁTY Ph.D. Eng.

Research and Technical Specialist at the Department of Evaluation of Operational Properties Oil and Gas Institute - National Research Institute 25 A Lubicz St. 31-503 Krakow E-mail: magdalena.zolty@inig.pl

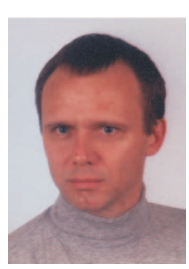

Jan LUBOWICZ Ph.D. Eng.

Research and Technical Specialist

Head of the Department of Fuels and Catalytic Processes Oil and Gas Institute - National Research Institute 25 A Lubicz St. 31-503 Krakow E-mail:lubowicz@inig.pl 